Trinity University

Digital Commons @ Trinity

Philosophy Faculty Research

Philosophy Department

3-22-2011

\title{
A Sense of Life in Language Love and Literature
}

Lawrence Kimmel

Trinity University, Ikimmel@trinity.edu

Follow this and additional works at: https://digitalcommons.trinity.edu/phil_faculty

Part of the Philosophy Commons

\section{Repository Citation}

Kimmel, L. (2011). A sense of life in language love and literature. In A-T. Tymieniecka (Ed.), Analecta Husserliana: The yearbook of phenomenological research, CIX: Destiny, the inward quest, temporality and life (pp. 15-22). Dordrecht, Netherlands: Springer.

This Post-Print is brought to you for free and open access by the Philosophy Department at Digital Commons @ Trinity. It has been accepted for inclusion in Philosophy Faculty Research by an authorized administrator of Digital Commons@ Trinity. For more information, please contact jcostanz@trinity.edu. 


\title{
Lawrence Kimmel
}

\section{A Sense of Life in Language Love and Literature}

\begin{abstract}
The fundamental human activity of telling stories, extended into the cultural tradition of literature, leads to the creation of alternative worlds in which we find resonance with the whole range of human thought and emotion from different and often conflicting perspectives. Fiction has no obligation to the ordinary strictures that bind our public lives, so the mind is free, engaging in literature, to become for the moment whatever imagination can conceive. So we become, in fictive reality, madman and poet, sinner and saint, embrace and embody sorrow and joy, hope and despair and all the rag tag feelings that flesh is heir to. But the sense of our own lives bleeds into the lives of others and our characters are formed and our lives enriched or impoverished by the relationships we develop. Literature extends the possibilities and scope of human experience and understanding of relationships that vary in dimension and depth-that develop in their own ways broadly between the good, the bad, and the ugly. Some relationships are given, some chosen, some forced. Some are nurturing, some useful, some inspiring, some destructive. But in any event and in every instance our sense of life in the connective tissue of human relationships is transformed through literature.
\end{abstract}

In what follows, I will try to give a general account of literature as it provides a creative space in which a sense of life finds full expression, that is, where such human questions discover their origin and depth.

I have wondered about the question itself: $a$ sense of life? I know what or about a sense of humor, a sense of taste, a sense of proportion, a sense of propriety...but in what sense do we wonder about a sense of life?...and a sense of life in literature? Several senses come to mind: A sense of life in literature first attends to the vitality of expression in literature, the sense in which literature is a living resource and recourse of human reference and concern. A second sense concerns the resource itself, whether literature 
embodies and encompasses the field and manifold of meaning that gives expression to the diversity and depth of life. Even more basically, I suppose we could wonder whether life has a sense at all, whether it makes sense, whether it can be given some definite sense. But the question here is not and is rightly not about knowledge. To ask for a sense of something, is to ask for a prior and deeper, and more intimate thing than knowledge. It is to ask for a feeling, a perception, a discernment, a purpose, a reason, a meaning, a thread of understanding... In our case we want an intimation, a presentment of sense that literature can bring to our understanding of ourselves, of our individual and collective lives.

By some miracle of life, human beings are graced with the capacity of speech. It sets us apart from the whole of the natural world in which life is ordered by instinct and bound by necessity. Aristotle's definition of Man as a creature with logos summarized an already long history of discourse about the facility of language and the ensuing and compelling interest of human beings in expressing the meaning of their existence. Human life centers in this capacity in such a way that the meaning of human life grows out of the activity of logos. The fact that human beings are creatures graced with reflective consciousness, with the capacity for giving expression to their lives, begins the tradition of telling stories. There is a compelling impulse to put our lives into some coherent story to understand the meaning of our lives individually and collectively.

'Sense of life' is an expression that seems to carry a depth that, by comparison, the simple fact of being alive does not bring with it and does not entail such a sense. Rather, developing a sense of life requires that one have reflective distance, have a 
perspective on her own activities and commitments and the corresponding activities of those around her. There is arguably a sense of life apparent in some straight-forward way of 'being alive', in that understanding requires reflection even in the mundane and everyday interactions we have with others and the world. But in the life of creative literature (and I will be referring throughout only to great literature) we are released from the yoke of everyday factive existence into a fictive world in which there is a tear in the fabric of ordinary time and place, in which a world of imagination opens to past and future, to what has never been and could or could not ever be. It is in such a world that a sense of life may discover its source.

The great virtue of literature in the telling of stories is the creation of alternative worlds in which we find resonance with the whole range of human thought and emotion from different and often conflicting perspectives. Fiction has no obligation to the ordinary strictures that bind our public lives, so the mind is free to become for the moment whatever imagination can conceive. So we become, in fictive reality, madman and poet, sinner and saint, embrace and embody sorrow and joy, hope and despair and all the rag tag feelings that flesh is heir to. But the sense of our own lives bleeds into the lives of others and our characters are formed and our lives enriched or impoverished by the relationships we develop. Literature extends the possibilities and scope of human experience and understanding of relationships that vary in dimension and depth-that develop in their own ways broadly between the good, the bad, and the ugly. Some relationships are given, some chosen, some forced. Some are nurturing, some useful, some inspiring, some destructive. But in any event and in every instance our sense of life in the connective tissue of human relationships is transformed through literature. 
In this most obvious and general way the characteristic activity of human beings, is comprehended in language. We do not merely behave, as lower forms of life do; we have the faculties necessary to act and in the process become aware that it is language that provides the distance for reflection that in turn enables action. But action, conceived in freedom, also is intended to fit into some ongoing and meaningful story of a life. Individually and collectively, we live within the stories we tell of our mutual lives.

The point to understand here is that story telling is not some late invention of a refined culture; it is rather a fundamental activity of human-being. We sometimes think of literature as centered in and responding to this primal activity-a compounding exercise of the energy focused in logos. The sense of life of an individual or of a people is carried by a narrative, by a story line that holds the sense of it all together. Myth, the elemental form of narrative expression, is a natural outgrowth of the freedom of human imagination. As mythic expression develops into a tradition and separate body of human activity in the tradition of literature, it sets itself apart in its proliferation of stories and perspectives on possible lives, on possible ways of living.

We can mark the evolution of culture in the form of stories that record a particular era or a particular people. But that too-history—is a story we tell in terms of the interest we have in our own past. We fashion the past in ways that provide us with the continuing sense of our own lives. So long as we comprehend the past in stories it remains a resource for the continuing and living thread of our existence as human beings.

In any given period there is a retrospective on culture, on the sense of history as it leads up to one's own time. We want to have some sense of what we have come through, of what we have learned about how to survive and prevail, and we look to the body of 
historical literature for links and inklings to the resources that exist for endurance and renewal.

But apart from the documents that record the events of history, and which seek out coherent meaning in the conflicting tensions of public life, there also is a parallel record of creative activity which is reflective of the deeper life of individuals embedded in the sweep of history. In an important sense the world of imaginative literature is a spiritual repository—it constitutes a diverse realm of fictive reality open to every speaker and reader of a natural language. In the world of this literature we are drawn into the fictive life of an era, into the characters and concerns of actors within that era, and find therein—in the activity and lives within this fictive reality—perspectives and resources for our own lives.

There is a remark of Santayanna's that a people who fail to understand their history are doomed to fulfill it (not "repeat it" as it is often misquoted and attributed to Winston Churchill in after-dinner speeches.) We may indeed need to reflect upon past mistakes that determine the present, that if, unheeded, project a future we should if possible avoid both as individuals and as a people. But the great value of the history of literature is that it is a place of possibilities, not a record of necessities. Whatever imperatives are discovered therein have only the binding force of choice. The world of fictive literature exists as a resource apart and embodies a wealth of generative power on which we can draw without apologies to the past.

Nietzsche searched the archaic literature of the Greeks to find a sense of mythic vitality that could model a renewal of moral and spiritual life. He looked past the rational paradigms of Greek philosophy to the tragic poets, to the passion embodied in a literature 
that could find virtue in the aspiration to great deeds not bound by rational mediation. The point here is not that Nietzsche was right in his moral advocacy, but that he had a sure sense for the vital life of literature. Among Nietzsche's sweeping remarks in his early book on The Birth of Tragedy was an analysis of the crucial role of myth in culture. This was a book which Nietzsche himself later characterized as youthful exaggeration, but apart from any rhetorical excess, it serves to recommend a critical resource for understanding the life of mythos — story — and the importance of literature in the life of a people: We are now

...able to approach the once-living reality of myth only by means of intellectual constructs. Yet every culture that has lost myth has lost, by the same token, its natural, healthy creativity...Man today stripped of myth, stands famished among all his pasts and must dig frantically for roots, be it among the most remote antiquities.

Again, we need not concur with Nietzsche's lament about the present age, but may better appreciate the need to renew our sense of the life to be found in the stories of our lives.

In our reflections about the body of literature that we have available to us, the genre of story-mythos - is crucial; it is the crucible from which the rest of literary genres emerge. But we should be mindful again of the even earlier focus of logos, of (literally) 'word'. Literature does indeed embody stories that draw on the expression of language that makes possible coherent lives through which we understand ourselves. But prior even to the stories we tell, there is a power of the word alone that we should acknowledge. The structure of speech, of language, is such that before the sentence as a element of meaning, we have the word. The power of words themselves to capture thought, the facility that words have to fix our thoughts, bind our sensibilities is elemental to meaning. The magic of words is hardly a mystery to those who read poetry, or enjoy a 
story, but there is a special reverence for words which is functional, for example, in the lives of a tribal people still living in an oral culture. Scott Momaday, speaks of his grandmother in House Made of Dawn, an old Kiowa woman, whose use of language was confined to speech such that her regard for words was always keen in proportion that she depended upon them: for her, words were medicine; they were magic and invisible.

Momaday goes on to remark that the tradition of telling stories is an act by which human beings strive to realize the capacity for wonder, meaning and delight, that the possibilities of storytelling are precisely those of understanding the human spirit.

In particular, the mix of language and human imagination results in the magic of metaphor, in the capacity of words to open and stretch the mind to comprehend seeming contradictions. Metaphors form the living tissue of the genre of poetry, no longer bound by narrative line, a form of thought and feeling in which language is crystallized into images that quicken the sense of whatever it touches.

By contrast, ordinary language is used and used up in the activity of speech. Political language, where it is not misused in rhetorical persuasion, is committed to fix boundaries of human relationships in law and legislation. Scientific language is similarly determined in its systematic structuring. Religious language binds itself in rite and ritual. Surely the language of literature is not alone in the employment of creative expression, but it is singular in its celebration of the imagination and is bound by no theory, or policy, or ritual in its modes of expression. It can delight in the free expression of language and direct its appeal not only to human possibilities but the full reach of human imagination that defines the world of reality. 
Mallarme reminded us that poetry is not written with ideas, but with words. But in the work of art, words open up into a world of meaning and truth. Goethe wrote that literature has its own depth and power, crystallizing the highest moments of surface phenomena, discovering in them the dignity of significance, the height of passion. There are no apparent limits to the expression of language in literature and while the discourse of literature can intensify the sense of reality, Wordsworth reminds us that it can also discover the still sense of humanity that chastens and subdues. While the painter works to discern and express the outward forms of things, the poet seeks the depths of inner life. In these and other ways, the languages of art deepen and broaden our sense of life.

The aesthetic experience invites a different perspective from the mundane ease of everyday life, but it also engages a focus different from the abstractions of theory or the juridical discourse of morality. The task of the artist, as da Vinci expressed it is saper vedere to learn and know how to see, and then, of course, to lend out her mind so that others may see in new and different ways. Aristotle put it that we see the world through our language; the languages of the arts, by extension, are lenses through which we see the range of possibilities open to imagination, of emotions, of relationships, of forms of life that enrich our own.

The genius of literature, even what we think of as philosophical literature, is less the pursuit of transcendent ideals than discovering a depth of immanence in the appearance and complex surfaces of the life-field of human activity. We are, as human beings, born into language. It is through the learning of speech that we become human beings. As Von Humboldt expressed it in the most basic and general terms it is only speech that enables a person to be the living being he is as man. But something more is 
needed here. There is a standardizing use and abuse of language that can rather distract and disengage us from a sense of the life of language. If we think only of and in the language of everyday discourse, there a failure of translation into the full meaning of human life. Our sensibilities are often enough dulled simply through the commonplace of routine. It is a continuing task of fictive literature to keep the imagination alive to the finer and deeper sensibilities of the human spirit. The tortured language of Heidegger's search for a poetic idiom free from the metaphysics of traditional grammar and from the calculating perspectives of contemporary culture is a philosophical measure of the problem. From the anguish embedded in that philosophical impasse one may be encouraged to return, and in a manner less encumbered than Heidegger's, to the simple expressions of sense and life found in poetry itself.

Regarding the irregular insights of the imagination in literature, Shakespeare in Midsummer Night's Dream famously remarks that the seething brains of poets, lovers and madmen apprehend more than is open to cool reason—-the lunatic sees more devils than vast hell could hold, the lover in the grip of passion sees Helen's beauty in a passing moment, while the poet, as imagination bodies forth, discovers forms of things unknown, turns them into intelligible meaning and gives to airy nothing a local habitation and a name.

In the broad corpus of world literature both realistic fiction and representative art exist which form only an extension, albeit meaningful, of shared and ordinary sensibility. But the experience of a fictive break from the ordinary of experience itself gathers imagination into its own world and provides a reflective depth of vision into both the larger and deeper meanings of life. It is a common experience that it is in the disruptions 
of our lives that we are brought to a more acute sense of meaning. Fictive literature draws on the same kind of disjoint-we are cut free from the ongoing currents of life, and drawn into the reflective ground of possibility.

\section{III}

The picture I am trying to capture here in the unique frame and activity of literature is the concrete immediacy of visceral imagination as it opens into an understanding of the sense of life-how literature both disconnects and reconnects the resource of imagination to our quickened sense of life. As Momaday's remarks above suggest, logos exists in primal forms even in the modern world. In tribal cultures that still center their cultural life in spoken language authors tend to write in the spirit of telling stories in the remembered sense of living voices. Many of these writers were graced by a poverty of space and disconnect of time growing up within a tradition not under the obsession or urgency of print--of speaking not yet reduced to writing, of talking not yet reduced to e-messages or media sound bites. This literature testifies to some degree that there is still an accessible cultural model, in this case preserved in story telling, in sand paintings, dances, and curing sings that celebrate and keep alive a vital sense of life. But the terms of accessibility here also suggest that stories must be lived, must be experienced in both the shared silence of intimate association and in the public turmoil of a continuing tradition within which they are told and heard. In an oral tradition there is no point of beginning or end, only telling of the same stories which are never the same, which simply take up and leave off: the residual wisdom of time and place come to presence only in the occasion of their telling. The lesson in this is that a living culture is sustained even against a dominant and static civilization through stories 
that are shared. What is vital in any culture may be found in the form as well as the content of the stories that are told. The frame of literature that defines a generation or a people can create a sense of common dwelling, a sense of sacred place no less than secular space of mutual understanding and acknowledgment.

It is irresistible in this context to cite the familiar but keenly moving moment in the life of the deaf and blind child Helen Keller when she first discovered language, and the sense of life it opened to her. In the still dark of her life she had no strong sentiment or tenderness until her teacher came into her life. Despite repeated efforts over months of teaching Helen to spell, to move her fingers, she learned only to make 'monkey-like imitations.' But walking with Ms. Sullivan her teacher into a well-house one morning when someone was drawing water, her teacher placed the child's hand under the water:

As the cool stream gushed over one hand she spelled into the other the word water, first slowly, then rapidly. I stood still, my whole attention fixed upon the motions of her fingers. Suddenly I felt a misty consciousness as of something forgotten - a thrill of returning thought; and somehow the mystery of language was revealed to me. The living word water awakened my soul, gave it light, hope, joy, set it free. There were barriers still, it is true, but barriers that could in time be swept away.

Everything now had a name and each name gave birth to a new thought, and each thing she touched now seemed to quiver with life, and indeed in time the barriers were swept away. In the reading of this remarkable document, from The Story of My Life written later by this remarkable woman, it is plain to see not only the power of language, but the incredible strength of the human spirit awakened by language.

\section{IV}

The provocations of fiction bring not only an acute sense of life to the living of it, but bring also the creative and paradoxical distortions of sense. The familiar genre of 
tragic literature contextualizes the extreme anguish of questioning existence, for example in the crushing paradigm of Macbeth's realization that all our hopes and yesterdays may be brought not only to dusty death, but resolve into a sound and fury, signifying nothing.

While literature invites reflection it is also self-reflective so that the value of words and reflection can themselves be brought into the contrast of paradox. Consider Addie's memorable soliloquy in Faulkner's As I lay Dying: in which she is struggling to express a sense of life, in her discovery as a teacher, as a mother, as a living person, of the inadequacy of language:

I knew that motherhood was invented by someone who had to have a word for it because the ones that had the children didn't care whether there was a word for it or not. I knew that fear was invented by someone that had never had the fear; pride, who never had the pride. I knew that it had been, not that they had dirty noses, but that we had had to use one another by words like spiders dangling by their mouths from a beam, swinging and twisting and never touching, and that only through the blows of the switch could my blood and their blood flow as one stream.

One is here reminded of Nietzsche's insistence that one must write as if with her own blood. Even so, of course, the claim of the inadequacy of words requires words for its expression. Victor Fankl famously noted, in his recollections of the dreadful extremes of experience of survival in the death camps in Germany and Poland, that human beings seem to be creatures who need meaning—logos—simply to survive. Sartre speaks of the common thread of suicide as an impasse of spirit, in which an individual has lost any sense of a project that would draw her into the future. The sense of life contextualized by literature is dramatic rather than discursive; there is no continuous thread of meaning but discontinuous episodes in human possibility. From mythic and tragic literature to lyrical expressions and comic vignettes, literature surprises and pleases, terrifies and reassures, it 
gives us leave of the binding insistencies of life, and like the grace of sleep can knit up the raveled sleeve of care.

People are drawn to literature for as many reasons as there are human beings with intelligence: some seek only relief or entertainment, for others it is challenge, or insight, or understanding, and for some reassurance or solace. But whatever the reason, within the space of literature a world appears in which the perennial questions of life: of truth, happiness, beauty, death, and the sacred come to presence and find resonance with human need.

So far we have left out the theme of love as it engages our sense of life in language and literature. Eros/ Philia/ Agape: there is a sense in which love holds dominion in the search for a sense of life, or rather it is the fabric within which sense runs the course of any life which has a sense. All inquiry begins with a sense of lack, a longing for what would complete the emptiness of desire. Aristotle, after explaining why poetry is more philosophical and more worthy of serious attention than history, once again speaks from the beginning to the point: all men desire to know, and philosophy (that is, the love of and search for wisdom) begins in wonder, in a sense of wonder. As language unfolds into literature and literature opens into and enfolds the sense of life we have a resource that we can enter at any point to discover therein the sense of our lives. There is, of course, only promise not certainty that literature will provide the insight needed to locate one in the larger sense of meaning that constitutes humanity in all its diversity. There is an old adage that a book is like a clear pool: if an ape peers in, one cannot expect an angel to peer out. We may or may not have grown any new emotions since our emergence from the primal forests or Eden, and the sense of life may or may not have 
been accessible and a resource of understanding throughout our journey. But here we are, in medias res, surrounded by centuries of expression that genius has wrought. If we come to this resource with wonder still alive in our hearts, then the sense of life that literature holds in trust will reward our presence.

If needed (I did not think footnotes necessary here) this is the information on the three citations:

F. Nietzsche, The Birth of Tragedy, N.Y., Vintage Books, 1967 Section 23, p. $135 \mathrm{ff}$.

W. Faulkner, As I Lay Dying, N.Y. Random House, 1964 Addie, p.163-4

H. Keller, The Story of My Life, N.Y. Doubleday, 1954 Chapter IV, p.36 